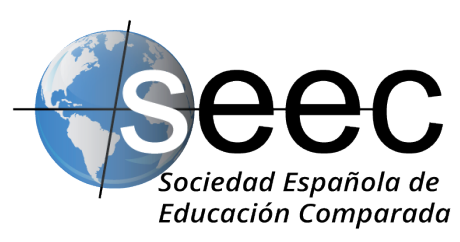

\title{
Impacts of Child Labour on School Attendance and Academic Performance of Senior Secondary
School Students in Nigeria Performance of Senior Secondary
School Students in Nigeria
}

Impacto del trabajo infantil en la asistencia escolar y el rendimiento académico de los estudiantes de secundaria superior en Nigeria

\section{Adesoji Oni*}

DoI: $10.5944 /$ reec.32.2018.22880

\author{
Recibido: 12 de octubre de 2018 \\ Aceptado: 11 de diciembre de 2018
}

\footnotetext{
*AdEsoJI OnI: Adesoji ONI a Fulbright Scholar holds a Ph.D in Sociology of Education From The University of Ibadan, Ibadan Nigeria. His area of research focus includes; social problems in education, social change in education, social deviances/ social disorganizations in Education with particular focus on students' secret cult in Nigeria. He has published widely in these areas. He is currently a Senior Lecturer in the Department of Educational Foundations, University of Lagos, Nigeria, where he teaches, Sociology of Education and Foundational studies in Education both at the undergraduate and graduate levels. Datos de contacto: E-mail: aoluoni@yahoo.com
} 


\title{
Resumen
}

Este estudio investigó el impacto del trabajo infantil en la asistencia escolar y el rendimiento académico de los estudiantes de secundaria en el área del gobierno local de Mushin en el estado de Lagos, Nigeria. Se probaron cinco hipótesis. La modalidad elegida para el estudio fue la investigación descriptiva. Un total de 300 encuestados fueron seleccionados de entre los estudiantes de seis (6) colegios de secundaria de nivel superior dentro del área del gobierno local de Mushin del estado de Lagos mediante una técnica de muestreo aleatorio simple. El instrumento de investigación utilizado fue un tipo de cuestionario Rensis Likert Rating Scale de cuatro puntos. El análisis de los datos se realizó utilizando estadísticas descriptivas de conteos de frecuencia, porcentaje y media para responder a las preguntas de la investigación, mientras que las hipótesis formuladas se evaluaron utilizando la herramienta estadística Chi-square y t-test independiente al nivel de significancia de 0.05. El estudio concluyó que hubo un efecto significativo de la exposición de los estudiantes al trabajo infantil en la asistencia escolar, el rendimiento académico y el hábito de estudio de los estudiantes de secundaria superior en el área del gobierno local de Mushin en el estado de Lagos. Además, hubo una diferencia significativa en el rendimiento académico de los estudiantes expuestos al trabajo infantil y aquellos que no lo estaban, entre los estudiantes de secundaria superior en el área del gobierno local de Mushin en el estado de Lagos. Pero no hubo una diferencia significativa en la asistencia a la escuela de los estudiantes expuestos al trabajo infantil y los que no lo estaban, en estudiantes de secundaria superior en el área del gobierno local de Mushin en el estado de Lagos. El estudio recomendó que el gobierno federal de Nigeria debería trabajar en la erradicación de la pobreza al proporcionar empleos a sus ciudadanos, que es la causa principal del trabajo infantil. El gobierno / la comunidad deben desarrollar estrategias positivas para la reducción del trabajo hacia un desempeño fructífero de la escuela infantil. asistencia y desempeño académico, tales como: presentar más subsidios, como boletos de comida gratis y gastos escolares reducidos, y que los programas de Educación Básica Universal (UBE, por sus siglas en inglés) deben implementarse y monitorearse por completo para cuidar la exposición al trabajo de estos niños.

Palabras clave: Trabajo infantil; Asistencia a la escuela; Desempeño académico

\begin{abstract}
This study investigated the impacts of child labour on school attendance and academic performance of secondary school students in Mushin Local Government Area of Lagos State, Nigeria. five hypotheses were tested. The descriptive research design was adopted for the study. A total of 300 respondent were selected from six (6) senior secondary school students within Mushin Local Government Area of Lagos State using simple random sampling technique. The research instrument used was a four point modified Rensis Likert Rating Scale Questionnaire type. Data analysis were done using descriptive statistics of frequency counts, percentage and mean to answer the research questions, while the hypotheses formulated were tested using Chi-square and independent t-test statistical tool at 0.05 level of significance. The study concluded that there was a significant effect of students' exposure to child labour on the school attendance, academic performance and study habit of senior secondary school students in Mushin Local Government Area of Lagos State. Also, there was a significant difference in academic performance of students exposed to child labour and those that are not in senior secondary school students in Mushin Local Government Area of Lagos State. But there was no significant difference in school attendance of students exposed to child labour and those that are not in senior secondary school students in Mushin Local Government Area of Lagos State. The study recommended that the federal government of Nigeria should work towards the eradication of poverty by providing employments to its citizens, which is the primary cause of child labour, the Government/Community should develop positive strategies to labour reduction towards a fruitful fulfillment of children's school attendance and academic performance, such as: introducing more subsidies such as free meal tickets and reduced school bills and that the Universal Basic Education (UBE) programs should be fully implemented and monitored to take care of these children exposed work.
\end{abstract}

Key Words: Child Labour; School Attendance; Academic Performance 


\section{Introduction}

Every child has the right to health and education. Yet each year, millions of under aged children around the world are engaged in remunerated or unremunerated work, leading to the impairment of their personal development and safety and often affecting also the physical and mental well being. Education is compulsory and a right of every Nigerian irrespective of gender, social status, religion, colour, ethnic background and any peculiar individual challenges (FRN, 2013). This philosophy of Nigeria education is based on the development of the individual into a sound and effective citizen and the provision of equal opportunities for all citizens of the nation at the basic, secondary and tertiary levels both inside and outside the formal school system.

Child labour which is defined as the admission to employment of a child, who is still within the age of compulsory school education, still remains a huge global problem which has precipitated an intense debate in the past few decades (Dammert, 2008). The concept of child labour seems complex in its nature. The word child labour is a combination of two components, namely; child in terms of his chronological age, and labour in terms of its nature, quantum and income generating capacity (Jayanti, 2008). The word labour is a controversial concept to define, especially in the context of child labour, child work and child labour are often used synonymously.

According to Obayelu and Okoruwa (2014), child labour seems a widespread phenomenon in the world's economies and has been for generations. It encompasses numerous complexities which call for elaboration and clarification for better understanding of the concept. It is often confused with child work, but in recent time it has been put in the spotlight by activists, politicians and economists alike. Most of the popular discussion has centered on the harmful effects of child labour and ways to curtail its incidence. Much of the recent theoretical literature in economics, has focused attention on how child labour is most likely a household decision (Basu, 2009).

With regard to the conceptual and definitional problems concerning child labour there are two schools of thought. According to the first school known as abolitionist school, education should be made a fundamental human right of every child in 5-14 age groups, and any child who is out of school should be treated as a potential working child (Dammert, 2008). They feel that elimination of child labour and attainment of compulsory basic education are two sides of the same coin and one cannot be achieved without achieving the other. According to them, the distinction between hazardous and non-hazardous work is immaterial (Pandiaraj, 2006).

According to the second school known as reformist school, child labour is a harsh reality, which means, given the socio-economic conditions (like poverty, unemployment and illiteracy) it is impossible to root out the problem of child labour altogether. They feel that elimination of child labour should be viewed as a long-term goal to be achieved progressively. Hence, they advocate a dual approach of prohibition of child labour in hazardous work and regulation of it in non-hazardous work (Laxmidhar, 2000).

Child labour seems so widespread in Nigeria that it has been accepted by many as part of normal life. The practice is only an aberration which takes away the innocence of millions of children; it is a threat to the future of the country (Nwiro, 2010).

Baland and Robison (2000) note that when parents are altruistic toward their children, have the ability to leave a bequest to their children, and have free access to capital markets, then investment in their children's education will be efficient. Problems with 
inefficient child labour arise when families are credit-constrained (Laitner, 1997; Parsons and Goldin, 1989; Jacoby and Skoufias, 1997). Thus, if parents expect family income to be rising over time, then they may find it optimal to borrow against the future for smooth consumption across time. That is, it is optimal for savings to be negative when children are young. In the child labour scenario, parents borrow from the future by putting their children to work rather than investing in human capital that will make their children more productive in the future. Such a strategy, while optimal for the family in this constrained situation seems not efficient. The present discounted value of another hour of schooling tends to be greater than the return to another hour of work.

United Nations International Children Education Fund (UNICEF) (2007), states that, child labour remains a major source of concern, in spite of legislative measure. According to the International Labour Organisation (2015), the number of working children under the age of 14 in Nigeria is estimated at 15 million. The high level of diverse and tedious jobs that children execute in dangerous circumstances is particularly worrying. These jobs include being street vendors, beggars, car washers or watchers and shoe shiners. Others work as apprentice mechanics, hairdressers and bus conductors, while large number works as domestic servants and in the farm (UNICEF, 2007).These children who work suffer from Fatigue, irregular attendance at school, lack of comprehension and motivation, improper socialization, exposure to risk of sexual abuse, high likelihood of being involved in crime. Research also shows that child workers display poor educational achievements (UNICEF, 2007).

International Labour Organisation(ILO) (2006), suggests poverty is the greatest single cause behind child labour. For impoverished households, income from a child's work is usually crucial for his or her own survival or for that of the household. Income from working children, even if small, may be between 25 to 40 percent of the household income, other scholars such as harsh on African child labour, and Edmonds and Paucnik on global child labour have reached same conclusion(United Nations, 2008; Edmonds and Pavcnik, 2005).

Academic performance on the other hand is how pupils or students deal with their studies and how they cope with or accomplish their different task given to them by their teachers. Onomodeke (2005) observed that for a pupil or student to be successful in his or her academic performance, the pupil has to be regular in school, face learning problems squarely, avoid late coming to school and he or she should consult with the teacher. Yap (2003) pointed out that a child who attends school more frequently may influence the amount of knowledge he or she gains. However, the more the school attendance the less time a child has on labour activities.

School attendance by a child is found to be so highly correlated with the family income (Rossana 2001). Some children in Nigeria embarked on child labour, dropped out from school or could not go to school as a result of their family's financial situation. The children of the poor were expected to help towards the family budget, often working long hours in dangerous jobs for low pay, earning 10-20 \% of an adult male's wage (Gunnarsson and Orazem, 2003).

Studies on the interaction between child labour and academic performance produce a mixed grill of findings. There is indirect evidence that child labour limits a child's human capital development (Rosati \& Rossi, 2011). The World Bank (2012), using test scores data from a nationally representative survey of junior high schools in Cambodia, reports that work has a significant and detrimental effect on learning achievement, particularly 
among the eight-graders. The estimated results for literacy and numeracy test-scores (including children, parental, household and school characteristics) indicate that working everyday before going to school reduces literacy and numeracy test scores of Cambodian eight-graders both by about nine percentage points.

Using data from the survey conducted for Young Lives International Study in Ethiopia, Wohldehanna and Gebremedhin (2015) show that child labour has a negative impact on children's raw test scores. Hence, there is clear causal evidence that child labour has adverse effect on children's educational performance. They conclude that overall, child labour exhibits a negative effect on children's educational achievement. The study of Guarcello, Lyons, and Rosati (2005) with a sample of 600 working children aged $12-14$ years in grades $7-10$ in Kenya indicates that only exclusive involvement in economic activity appears to be detrimental to academic achievement; 56 percentage are rated as either "poor" or "very poor" in terms of academic performance, compared to 37 percent of non-working children. Children involved in household chores rate higher than nonworking children in terms of school performance. They conclude that not working will improve students' performance for most children in all work categories.

In the light of the above issues, this study tends to assess the effect of child labour on school attendance and academic performance of senior secondary school students in Mushin Local Government Area of Lagos State.

\section{Statement of the Problem}

The irregular school attendance and poor academic performance of secondary school students are big problems hindering the achievement of our National Educational Goals. There are increase in the rate of secondary school dropouts, examination malpractice and unskilled labour force in Nigeria.There are factors according to different studies that may be responsible for this national problem, which are examination malpractice, school environment, truancy, family background, poor funding of educational system, poor teacher's motivation, among others. However, another factor that needs our consideration to solve the problem of irregular school attendance and poor academic performance is child labour. Most children were engaged in child labour with some working exclusively while others combine schooling with child labour. In addition to being hazardous and harmful to children health, child labour interferes with education.

The failure of children to attend school and perform better academically is of concern to the researcher due to their inability to combine school attendance with income generation activities. International Labour Organization (ILO, 2005) stated that about twenty six percent (26\%) of children aged ten to fourteen (10-14) years in Nigeria were engaged in economic activities. Hence, the magnitude of children's labour force participation in Nigeria served as a compelling reason to investigate the impacts of child labour for children's school attendance and academic performance. 


\section{Hypotheses}

The following hypotheses were tested in the study:

1. There will be no significant effect of students' exposure to child labour on the school attendance of senior secondary school students in Mushin Local Government Area of Lagos State.

2. There will be no significant effect of students' exposure to child labour on the academic performance of senior secondary school students in Mushin Local Government Area of Lagos State.

3. There will be no significant effect of students' exposure to child labour on the study habit of senior secondary school students in Mushin Local Government Area of Lagos State.

4. There will be no significant difference in school attendance of students exposed to child labour and those that are not in senior secondary school students in Mushin Local Government Area of Lagos State.

5. There will be no significant difference in academic performance of students exposed to child labour and those that are not in senior secondary school students in Mushin Local Government Area of Lagos State.

\section{Methodology}

Since descriptive survey research design is a research method which enables researcher to obtain opinions of a representative sample of a target population so as to infer the perception or view of the entire population. Thus, the descriptive survey research design was adopted in carrying out this study.

The population of the study comprises all students in public senior secondary schools in Mushin Local Government Area of Lagos State, Nigeria. The sample size comprises three hundred (300) respondents. The respondents were selected in their classes when the researcher visited their schools through stratified and simple random sampling technique. Mushin Local Government was divided into six (6) zones (Mushin, Illupeju, Papa-Ajao, Odi-Olowo, Ojuwoye and Idi-oro). Thereafter, the simple random sampling was used to select one (1) senior secondary school from each zones and 50 students from each school selected making it a total of 300 students. The ages of the respondents are between 12 and 20 all the sample schools are mixed school comprising of both male and female students. The selected senior secondary schools were mainly Government schools. The sample was selected by means of the simple random sampling technique. According to Omorogiuwa, (2006) samples resulting from the application of this procedure are said to be unbiased and therefore representative of the population. The simple random sampling was carried out through the use of slips of paper. To use this strategy, each school existing in Mushin Local Government area was assigned a number written on pieces of paper. The pieces of paper were then put in a bag from where one piece was picked at a time without replacement. The picked paper was then recorded and the 
process continues until the desired sample size of five schools was obtained. This is to ensure that each member of the population has an equal opportunity of being drawn.

A self-developed questionnaire titled Child Labour, School Attendance and Academic Performance Questionnaire (CLSAAPQ) was used as research instruments to collect the needed information from the respondents regarding the effect of child labour on school attendance and academic performance of senior secondary school students in Mushin Local Government Area of Lagos State. The questionnaire was divided into sections A, $\mathrm{B}$ and C. Section A presents information relating to demographic data of the respondents. Section B presents items that seek to answer the research questions raised and the respondents were instructed to tick the item that is most appropriate. Four Likert scale types of rating, which are Strongly Agreed (SA), Agreed (A), Strongly Disagreed (SD) and Disagreed (D) was the format of the questionnaire while section C presents questions to test the students' achievement in English language and general knowledge. The questionnaire was personally administered to the respondents by the researcher so as to provide additional information and explanation where needed. The completed questionnaires were collected immediately to avoid misplacement or loss.

The research instrument (questionnaire) that was distributed was given to experts in the area of measurement and evaluation for vetting, assessment and correction to ensure face and content validity. The test- retest method was adopted in determining the reliability of the questionnaire. The questionnaire was administered on selected 10 students and later in another one week the same set of questionnaire was administered on the same set of students. The Correlation Coefficient of the test instrument was ascertained by using the Pearson Product Moment Correlation (PPMC). Reliability co-efficient of 0.79 was attained and considered good for the study.

Before the day/time of administering the research instruments, the researcher requested for permission from the respective school authorities in order to make use of their students as the research respondents. While the two research instruments (i.e. the questionnaire and the achievement test) were administered to the respondents on the same day, they were retrieved from them as soon as possible after administration.

The data collected was used to develop a frequency distribution table for analysis. The percentage method was used in presenting the data collected. While inferential statistics of chi-square $\left(\mathrm{X}^{2}\right)$ statistical tools was used in testing hypotheses 1-3. Independent t-test was used in testing hypotheses 4 and 5 at 0.05 level of significance. Chi-square was chosen because it is a statistics, which determine the relationship between two variables (the observed and the expected frequencies). Independents t-test on the other hand is an inferential statistical test that determines whether there is a statistically significant difference between the means in two unrelated groups. The t-test as a statistical was used in this regard to help to unravel difference between academic performance and school attendance of students exposed to child labour and those that are not. 


\section{Result}

\section{Data Presentation}

Table 1

Analysis of Demographic Data of the Respondents

\begin{tabular}{lll}
\hline Variable & Frequency & Percent \\
\hline Gender & & \\
Female & 160 & $53.3 \%$ \\
Male & 140 & $46.7 \%$ \\
Total & $\mathbf{3 0 0}$ & $\mathbf{1 0 0}$ \\
& & \\
Age & & \\
$12-14$ Years & 28 & $9.3 \%$ \\
$15-17$ Years & 244 & $81.4 \%$ \\
18 and Above & 28 & $9.3 \%$ \\
Total & $\mathbf{3 0 0}$ & $\mathbf{1 0 0}$ \\
Class & & \\
SS1 & 10 & $3.3 \%$ \\
SS2 & 180 & $60 \%$ \\
SS3 & 110 & $36.7 \%$ \\
Total & $\mathbf{3 0 0}$ & $\mathbf{1 0 0}$ \\
Area of Study & & \\
Science & 114 & $38 \%$ \\
Arts & 104 & $60 \%$ \\
Commercial & 82 & $36.7 \%$ \\
Total & $\mathbf{3 0 0}$ & $\mathbf{1 0 0}$ \\
Engagement & & \\
in Child Labour & 134 & $\mathbf{1 0 0}$ \\
No & 166 & \\
Yes & $\mathbf{3 0 0}$ & \\
Total & & \\
\hline
\end{tabular}

Information on table 1 shows that $160(53.3 \%)$ of the respondents were female while $140(46.7 \%)$ of them were male. This implies that majority of the respondents were female. The table also reveals that 28(9.3\%) of the respondents were students between the ages of 12-14 years, $244(81.4 \%)$ of them were students between the ages of $15-17$ years while 28(9.3 \%) of them were students between the ages of 18 and above. This implies that majority of the respondents were students between the age of 15-17years. The table further reveals that, 10(3.3 \%) of the respondents were SSS1 students, $180(60$ \%) of them were SSS2 students while 110 (36.7 \%) of them were SSS3. This implies that majority of the respondents were SSS2 students. The table also reveals that 114(38 \%) of the respondents were Science students, 104(34.7 \%) of them were Arts students while $82(27.3 \%)$ of them were commercial students. This implies that majority of the 
respondents were science students. Lastly, the information on table 1 shows that $134(44.7$ $\%)$ of the respondents did not engage in work/job before and after school while 166(55.3 $\%$ ) of the respondents engage in work/job before or after school hours. This implies that majority of the respondents engage in job before or after schools hour.

\section{Hypotheses Testing}

\section{Hypothesis 1}

There will be no significant effect of students' exposure to child labour on the school attendance of senior secondary school students in Mushin Local Government Area of Lagos State.

Table 2

Effect of students' exposure to child labour on the school attendance

\begin{tabular}{llllllll}
\hline Variables & $\mathrm{N}$ & Df & L.S & $\begin{array}{l}\text { Calc } \\
\text { value }\end{array}$ & $\begin{array}{l}\chi^{2} \\
\text { value }\end{array}$ & Remarks \\
\hline $\begin{array}{l}\text { Effect of students exposure to } \\
\text { child labour on their school } \\
\text { attendance }\end{array}$ & 300 & 12 & 0.05 & 39.13 & $\mathbf{2 1 . 0 3}$ & Ho $_{1}$ Rejected \\
\hline
\end{tabular}

(Calc. $\chi^{2}=39.13>$ Crit. $\left.\chi^{2}=21.03, \mathrm{df}=12, \mathrm{P}>0.05\right)$

Information on table 2 shows that the calculated Chi-Square $\left(\chi^{2}\right)$ value of 39.13 is greater than critical Chi-Square $\left(\chi^{2}\right)$ value of 21.03, with degrees of freedom of 12 at 0.05 level of significance. This implies that the null hypothesis which stipulated that there will be no significant effect of students' exposure to child labour on the school attendance of senior secondary school students in Mushin Local Government Area of Lagos State is hereby rejected. Therefore, there was a significant effect of students' exposure to child labour on the school attendance of senior secondary school students in Mushin Local Government Area of Lagos State.

\section{Hypothesis 2}

There will be no significant effect of students' exposure to child labour on the academic performance of senior secondary school students in Mushin Local Government Area of Lagos State.

Table 3

Effect of students' exposure to child labour on the academic performance

\begin{tabular}{llllllll}
\hline Variables & $\mathrm{N}$ & Df & L.S & $\begin{array}{l}\text { Calc } \\
\text { value }\end{array}$ & $\begin{array}{l}\chi^{2} \\
\text { value }\end{array}$ & $\chi^{2}$ Remarks \\
\hline $\begin{array}{l}\text { Effect of students' exposure to } \\
\text { child labour on the academic } \\
\text { performance }\end{array}$ & 300 & 12 & 0.05 & 62.18 & 21.03 & Ho $_{2}$ Rejected \\
\hline
\end{tabular}

(Calc. $\chi^{2}=62.18>$ Crit. $\left.\chi^{2}=21.03, \mathrm{df}=12, \mathrm{P}>0.05\right)$ 
Information on table 3 shows that the calculated Chi-Square $\left(\chi^{2}\right)$ value of 62.18 is greater than critical Chi-Square $\left(\chi^{2}\right)$ value of 21.03, with degrees of freedom of 12 at 0.05 level of significance. This implies that the null hypothesis which stipulated that there will be no significant effect of students' exposure to child labour on the academic performance of senior secondary school students in Mushin Local Government Area of Lagos State is hereby rejected. Therefore, there was a significant effect of students' exposure to child labour on the academic performance of senior secondary school students in Mushin Local Government Area of Lagos State.

\section{Hypothesis 3}

There will be no significant effect of students' exposure to child labour on the study habit of senior secondary school students in Mushin Local Government Area of Lagos State.

Table 4

Effect of students' exposure to child labour on the study habit

\begin{tabular}{|c|c|c|c|c|c|c|}
\hline Variables & $\mathrm{N}$ & Df & L.S & $\begin{array}{l}\text { Calc } \quad \chi^{2} \\
\text { value }\end{array}$ & $\begin{array}{l}\text { Crit } \\
\text { value }\end{array}$ & Remarks \\
\hline $\begin{array}{l}\text { Effect of students' exposure to } \\
\text { child labour on the academic } \\
\text { performance }\end{array}$ & 300 & 12 & 0.05 & 43.23 & 21.03 & $\mathrm{Ho}_{3}$ Rejected \\
\hline
\end{tabular}

(Calc. $\chi^{2}=43.23>$ Crit. $\left.\chi^{2}=21.03, \mathrm{df}=12, \mathrm{P}>0.05\right)$

Information on table 4 shows that the calculated Chi-Square $\left(\chi^{2}\right)$ value of 43.23 is greater than critical Chi-Square $\left(\chi^{2}\right)$ value of 21.03, with degrees of freedom of 12 at 0.05 level of significance. This implies that the null hypothesis which stipulated that there will be no significant effect of students' exposure to child labour on the study habit of senior secondary school students in Mushin Local Government Area of Lagos State is hereby rejected. Therefore, there was a significant effect of students' exposure to child labour on the study habit of senior secondary school students in Mushin Local Government Area of Lagos State.

\section{Hypothesis 4}

There will be no significant difference in school attendance of students exposed to child labour and those that are not in senior secondary school students in Mushin Local Government Area of Lagos State. 
Table 5

t-test analysis of the differences in school attendance of students exposed to child labour and those that are not

\begin{tabular}{|c|c|c|c|c|c|c|}
\hline Variables & $\mathrm{N}$ & Mean & Sd & t-calc. & t-crit. & Decision \\
\hline \multicolumn{7}{|l|}{ Exposed to } \\
\hline \multirow[t]{2}{*}{ Child Labour } & 166 & 14.78 & 2.64 & & & \\
\hline & & & 298 & 0.34 & 1.96 & $\mathrm{Ho}_{4}$ Accepted \\
\hline \multicolumn{7}{|l|}{ Not Expose to } \\
\hline Child Labour & 134 & 14.67 & 3.08 & & & \\
\hline
\end{tabular}

(t-calc. $=0.34<\mathrm{t}-$ crit. $=1.96, \mathrm{df}=298, \mathrm{P}>0.05)$

Table 5 shows t-test result of the differences in school attendance of students that exposed to child labour and those that did not. The table indicates that the means score of students that exposed to child labour is 14.78 while the mean score of students that does not exposed is 14.67. The calculated $t$-value of 0.34 is lesser than $t$-critical $(298)=$ 1.96 at 0.05 significant level. Hence, the null hypothesis that states that there will be no significant difference in school attendance of students exposed to child labour and those that are not in senior secondary school students in Mushin Local Government Area of Lagos State is accepted. It is therefore concluded that there was no significant difference in school attendance of students exposed to child labour and those that are not in senior secondary school students in Mushin Local Government Area of Lagos State

\section{Hypothesis 5}

There will be no significant difference in academic performance of students exposed to child labour and those that are not in senior secondary school students in Mushin Local Government Area of Lagos State.

Table 6

t-test analysis of the differences in academic performance of students exposed to child labour and those that are not

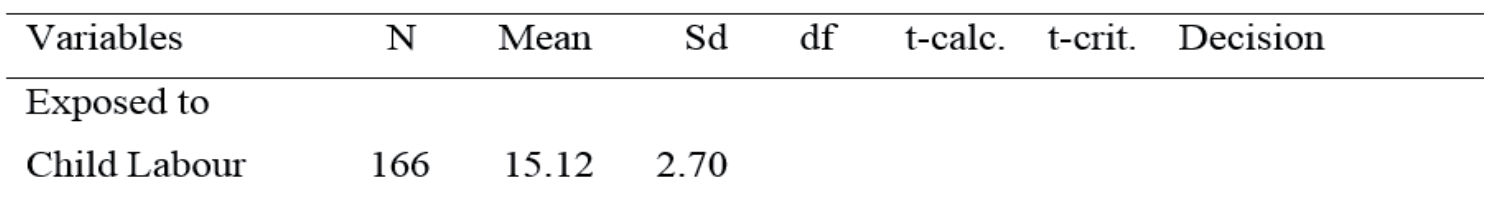

$298 \quad 3.31 \quad 1.96 \quad \mathrm{H}_{5}$ Rejected

Not Expose to

$\begin{array}{llll}\text { Child Labour } \quad 134 \quad 14.07 & 2.81\end{array}$

$(\mathrm{t}-\mathrm{calc} .=3.31>\mathrm{t}$-crit. $=1.96, \mathrm{df}=298, \mathrm{P}<0.05)$ 
Table 6 shows t-test result of the differences in academic performance of students that exposed to child labour and those that did not. The table indicates that the means score of students that exposed to child labour is 15.12 while the mean score of students that does not exposed is 14.07. The calculated t-value of 3.31 is greater than t-critical $(298)=$ 1.96 at 0.05 significant level. Hence, the null hypothesis that states that there will be no significant difference in academic performance of students exposed to child labour and those that are not in senior secondary school students in Mushin Local Government Area of Lagos State is rejected. It is therefore concluded that there was a significant difference in academic performance of students exposed to child labour and those that are not in senior secondary school students in Mushin Local Government Area of Lagos State.

\section{Discussion of Findings}

Hypothesis one stated that there is no significant effect of child labour on school attendance of secondary school students. The result shows that there was significant effect of child labour on school attendance of secondary school students. The calculated Chi-Square $\left(\chi^{2}\right)$ value of 39.13 is greater than critical Chi-Square $\left(\chi^{2}\right)$ value of 21.03, with degrees of freedom of 12 at 0.05 level of significance. This implies that students involvement in child labour have negative effect on their school attendance. Most of students that engage in work/job before and after school hours were perpetual late comer.

The finding is in line with the findings of Ray and Lancaster (2003) which investigated the effect of work on the school attendance and performance of children in the 12-14 year age group in seven countries in terms of the relationship between hours of work and school attendance and performance in which they concluded that hours spent at work had a negative impact on education variables, with the marginal impact weakening at the higher levels of work hours. The result also corroborated with the study carried out by Kvalsving (2008), who found that poor school attendance was caused by the requirements parents place on children to be economically active which resulted in the children going to school late or having interruptions in their schooling because of seasonal agricultural activities. The significant effect of child labour may be because these children, who combine work with schooling, seem suffer fatigue and stress which may cause irregular school attendance especially for those that hawk before going to school and those that work late at night. Again even when they attend school, they seem not to be actively participating in school activities.

Hypothesis two stated that there is no significant effect of child labour on academic performance of secondary school students. The result showed that there was significant effect of child labour on academic performance of secondary school students. The calculated Chi-Square $\left(\chi^{2}\right)$ value of 62.18 is greater than critical Chi-Square $\left(\chi^{2}\right)$ value of 21.03, with degrees of freedom of 12 at 0.05 level of significance. This implies that students that combined working with school have divided attention, lost focus and concentration and this have adverse effect on their academic performance. This agreed with Heady (2003), that balancing the demands of work and education places physical and psycho-social strain on children and often leads to poor academic performance and dropping out. The result also corroborates Barone (2003) conclusion that younger students working long hours performed more poorly than did working older students.

Hypothesis three stated that there is no significant effect of child labour on study habits of secondary school students. The result showed that there was significant effect 
of child labour on study habits of secondary school students. The calculated Chi-Square $\left(\chi^{2}\right)$ value of 43.23 is greater than critical Chi-Square $\left(\chi^{2}\right)$ value of 21.03, with degrees of freedom of 12 at 0.05 level of significance. This implies that working and studying students find it difficult to create extra time for study at home. This agrees with Akabayashi \& Psacharapoulos (2009) that a child's reading habit and mathematics ability decreased with additional hours of work, whereas they increased with additional hours of school attendance and study. The result was further corroborated with Emerson and Portela (2007) who reported that child labour could put children at a disadvantage physically, mentally, economically, socially and academically. The children that work after school hours hardly find time to study and do homework because they always come back late from work, even when they to study they too tired to do so and will feel sleepy.

Hypothesis four stated that there will be no significant difference in school attendance of students exposed to child labour and those that are not. The result shows that there was no significant difference in school attendance of students exposed to child labour and those that are not. The calculated t-value of 0.34 is lesser than t-critical (298) $=1.96$ at 0.05 significant level. This implies that students' involvement in working and studying did not affect their attendance in school. Meaning that working and studying students may come to school regularly but they may not be punctual, they may be perpetual late comer. This is in consonance with Psacharapoulos (2007) that child labour and schooling may be complementary activities. Also with Assaad (2003) who observed that low attendance of Egyptian girls relative to boys appeared to be associated with a substantial domestic work burden of girls, because boys did not face the same work burden within the home. They faced fewer barriers to schooling such that in the Egyptian data, they did not observe a tradeoff between working and schooling attendance for boys. The result is also in tandem with Werner (2006) who argues in favour of child labour. He stated that in many impoverished locales, child labour is all that stands between the family unit and all pervasive, life threatening, destitution. Just because they are under age does not mean that they should be rejected, they have a right to survive. One cannot just say that they cannot work, but should provide the alternatives. The fatigue and stress caused by child labour may lead to irregular school attendance and lack of participation in school attendance may contribute to poor academic performance of these children who were exposed to work and study.

Hypothesis five stated that there will be no significant difference in academic performance of students exposed to child labour and those that are not. The result showed that there was a significant difference in academic performance of students exposed to child labour and those that are not. The calculated t-value of 3.31 is greater than t-critical $(298)=1.96$ at 0.05 significant level. This implies that students that combined working with school have divided attention, lost focus and concentration and this have adverse effect on their academic performance while those that face this study without combining it with trade have full concentration on their study and have better chance of performing better than their working and studying students' counterpart. This is in line with Barone (2003) that younger students working long hours performed more poorly than did non-working students. Also with Singh (2008) that working long hours while in school did hurt standardized test scores and grades, although the effect was quite low. Stern (2007) found that working more than fifteen (15) hours per week while in school led to lower grades, less time spent on homework, increased likelihood of dropout and lower likelihood of entering school education. 


\section{Conclusion and Recommendations}

This study investigated the impacts of child labour on school attendance and academic performance of secondary school students in Mushin Local Government Area of Lagos State, Nigeria. This study has revealed the crucial effects of child labour on students' attendance and performance. The study showed that combined unstructured and unregulated work with schooling will negatively affect students' punctuality, attendance, study habit and academic performance of students. Based on the result from the findings of this study, it was concluded that there was a significant effect of students' exposure to child labour on the school attendance, academic performance and study habit of senior secondary school students in Mushin Local Government Area of Lagos State. Also, there was a significant difference in academic performance of students exposed to child labour and those that are not in senior secondary school students in Mushin Local Government Area of Lagos State. But there was no significant difference in school attendance of students exposed to child labour and those that are not in senior secondary school students in Mushin Local Government Area of Lagos State.

Based on the findings of the study, the following recommendations were put forward:

1. Children exposed to labour activities should be given equal right to attend school regardless of any engagement in labour activity.

2. The federal government of Nigeria should work towards the eradication of poverty by providing employments to its citizens, which is the primary cause of child labour.

3. The Government/Community should develop positive strategies to labour reduction towards a fruitful fulfillment of children's school attendance and academic performance, such as: introducing more subsidies such as free meal tickets and reduced school bills.

4. The Universal Basic Education (UBE) programs should be fully implemented and monitored to take care of these children exposed work.

5. The child right law should be fully implemented in Nigeria.

\section{References}

Abdulmumini, A.U. \& Mohammed, F.O. (2003). Effect of child labor and performance on child relationship with head in rural areas of Niger State, Nigeria. International Journal of Economics and Financial Issues, 2016, 6(3), 892-9oo.

Afolabi, P., Ayodele, J.B., \& Ajayi, I.A. (2009). Practices of child labour among parents in Ekiti state, Nigeria: Implication for school administrators. Journal of Education and Practice, 4(11), 1-7.

Anumaka, I.B. (2015). Impact of child labour on academic performance and social implication: A case of Northeast Uganda. Kampala: University Press. 
Azikiwe, U. (2008). Study approaches of university students. World Council of Curriculum and Instruction (WCCI), 2(1), pp. 106 - 114.

Babita-Agarwal, Y. (2007). Child Labour in India. India: ABD Publishers.

Barone, F.J. (2003). The effects of part-time employment on academic performance, in NASSP Bulletin, 76(1), 549.

Boozer, M., \& Suri, T. (2001). Child labour and schooling decisions in Ghana, (Unpublished Paper), Yale University.

Bossaert, G.; Doumen, S.; Buyse, E.; \& Verschueren, K. (2011). Predicting students' academic achievement after the transition to first grade: A two-year longitudinal study. Journal of Applied Developmental Psychology 32(3), pp. 47-57.

Dachi, H.A., \& Garret, M. (2004). Child labour and its Impact on Children's Access to and participation in primary education. A case study from Tanzania United Nations Report. 6(1), pp. 1-7.

Dammert, A.C. (2008). Child labor and schooling response to changes in coca production in rural Peru. Journal of Development Economics, 86, pp. $164-180$

Edmonda, V.E., (2005). Does child labour decline with improving economic state?, The Journal of Human Resources 40, pp. 77-99.

Edmonds, E. (2007). The economics of consumer actions against products with child labour content. Africa Child Report 2(9), pp. 12-14.

Edmonds, V.E. (2007b). Selection into worst forms of child labour. Child domestic porters, and regpickers in Nepal (Unpublished Paper) Dartmouth College, Hanover, $\mathrm{HH}$.

Epstein, J.L., \& Sheldon, S.B.,(2002). Present and accounted for: Improving student attendance through family and community involvement. Journal of Educational Research, 95(5), 308 $\square 318$.

Faraaz S. \& Patrinos A.H. (1999). Child labour: issues, causes and interventions. Palgrave: Macmillan

Federal Government of Nigeria (2013) Nigeria: National report presented to the 45th session of the International conference on Education, Geneva, 30 September - 5 October

Fetuga M. B; Njokanma O. F \& Ogunlesi T. A. (2013). Department of Paediatrics, Olabisi Onabanjo University Teaching Hospital Sagamu, Nigeria. International Journal of Educational Science and Research (IJESR) 6(1), pp. 55-60.

Fetuga, B.(2007). The impact of child labour on academic performance. Indian Journal of Pediatrics, 74(3), pp. 933-937.

Gamlin, J. \& Hesketh T. (2007). Child work in agriculture: Acute and chronic health hazards. Children, Youth and Environments Journal, 17(4), pp. 1-23. 
Garrison K.C. (1965). Psychology of adolescence, New Jersey: Prentice Hall Inc.

Government of Nigeria, (1990). Labour Act (Chapter 198) (No. 21), as amended. Laws of the Federation of Nigeria (1990 Revised edition), Retrieved July 12, 2015

Government of Nigeria, (2003) Trafficking in Persons (Prohibition) Law Enforcement and Administration Act, No. 24, enacted July 2003.

Government of Nigeria, (2003). Child Right's Act, No. 26, enacted July 31, 2003.

Hussain, M. \& Debnath, J., (2000). Issues and problems of girl child labour in India and Bangladesh. Journal of India Anthropology.35(1), pp. 255-70.

ILO Committee of Experts (2015). Individual direct request concerning forced labour convention, 1930 (No. 29) Nigeria (ratification: 1960) Submitted: 2012; Accessed November 29,2017.

ILO Committee of Experts (2015). Individual direct request concerning minimum age convention, 1973 (No. 138) Nigeria (ratification: 2002) Submitted: 2011; Accessed November 29, 2017.

ILO, (2006A). IPEC Action against child labour: Highlights 2006. Geneva: ILO.

ILO, (2008). Child labour - Causes. ILO Quarterly Review 3(6), pp. 45-47

IPEC, (2004). Child labour - A textbook for university students. Geneva: ILO, 2004. Available at: http://www.ilo.org/ipecInternational

Karine, L. (2009). The dark side of labour in China. New Jersey: Patience Hall

Kremer, T. (2004). Teacher absence in India: A snapshot. World Bank Report 7(2), pp. 7-19

Laitner, J. (1997). Intergenerational and inter-household economic links. In Mark R. Rosenzweig and Oded Stark, eds., Handbook of population and family economics, Amsterdam: Elsevier Press.

Lalek A., (2005). Quality progress-fifth quality in education listing. Quality Progress, 28(1), 27-77.

Lillydahl, J. H. (2010). Academic achievement and part-time employment of high school students, in Journal of Economic Education 21(2), pp. 307-316.

Nkamleu, G.B. (2009). Determinants of Child Labour and Schooling in the Native Cocoa Households of Cote d'Ivoire, AERCResearch Paper No. 19o. Nairobi, Kenya: African Economic Research Consortium.

Odusanya L.L. (2002). Student absenteeism and truancy: Technologies and interventions to reduce chronic problems among school-age children. Journal of Children, 7(1), pp. 23-34.

Oghuvbu, E.P. (2003). Attendance and academic performance of students in secondary schools: A correlational approach. International Journal of Education and Research, 2(10), pp. 417-436. 
Ogoemeka, O.H. (2013). Study habits skills components as predictors of academic performance among teacher trainees in Nigeria. Int. J. Educ. Res. 1(1), pp. 7-14.

Ononuju, J.N. (2004). The family and parenting in Nigeria's social development. Nigeria. Warri: Frontline Publication.

Orazem, P. \& Gunnarsson A., (2005). Child labour, school attendance, children, and performance. A review working paper no. 11177 Department of Economics, Lowa State University.

Ozsoy, G., Memis, A., \& Temur, T. (2009). Meta-cognition, study habits and attitudes. Available@ @ttp://www.iejee.com/2_9_2015/ozsoy.pdf

Patrinos, H. A, \& Psacharopoulos, G. (2007) Family size, schooling and child labourin Peru - An Empirical Analysis, Journal of Population Economics, 1O(4), pp. 387405.

Psacharopoulos, G (2007). Child labour versus educational attainment: Some evidence from Latin America, Journal of population Economies, 1O(4), pp. 337-286

Ray, R., (2003). The determinants of child labour and schooling in Ghana. Journal of Africa Economic 11(1), pp. $561-590$

Ready, D.D., (2010). Socioeconomic disadvantage, school attendance, and early cognitive development: The differential effects of school exposure. Sociology of Education, 83(4), pp. 271-286.

Rosati, F. C. \& Rossi, M. (2011). Child labour, school enrolment and human capital accumulation. Geneva: UNICEF.

Rosati, F.C. (2005, January). Child labour and education. Rome: ILO/UNICEF.

Rumberger R.W., (2007). High school dropouts: A review of issues and evidence. Review of Educational Research, 23(1), pp. 24-42.

Sanchez, M.A., (2005). The effect of child labour on Mathematics and Language Achievement in Latin America. Social protection discussion paper series. No. 0516. Washington D.C.: The World Bank.

Segal, C. (2008). Classroom behaviour. Journal of Human Resources, 43(1), pp. 783814 .

Singh, K. (2008). Part-time employment in high school and its effect on academic achievement, in the Journal of Educational Research 91(1), pp. 131-139.

Stern, D. (2007). Learning and earning: The value of working for urban students, ERIC Digest 9(3), pp. 32-41.

The Law Library of Congress, (2010). Africa child labor laws. Washington, DC: McGraw.

UNDP, (2003). Millennium development goals: A compact among nations to end human poverty. New York: Oxford University Press. 
UNICEF, (2009b). The challenge Available 2009-05-19 at http://www.childinfo.org/ labour.html

UNICEF, (2012). Percentage of children aged 5-14 engaged in child labour. Retrievedfromhttp://www.unicef.org/nigeria/children_1941.html

United Nations Convention on the Rights of the Child, (1999). FACT SHEET: A summary of the rights under the Convention on the Rights of the Child: http://www.unicef.org/crc/files/Rights. pdf

Wadesango, N. \& Machingambi, S. (2011). Causes and structural effects of student absenteeism: A case study of three South African Universities, J Soc Sci, 26(2), pp. 89-97

Yap, T., Guilherme, S \& Peter F. Orazem. (2003). Limiting child labour through behaviour-based income transfers: An experimental evaluation of the PETI programme. Washington, DC: McGraw.

Woldehanna, T. \& Gebremedhin, A. (2015). Is child world detrimental to the educational achievement of children? Oxford: Oxford Department of International Development (ODID). 